\title{
From Asymmetric to Polycentric Development: Pattern, Distribution and Stakeholder Analysis of Community Empowerment Program in Batu, Indonesia
}

\author{
Ayu Kusumastuti ${ }^{1}$, Nyimas Nadya Izana ${ }^{1}$ \\ ${ }^{1}$ Department of Sociology, Brawijaya University, Malang, East Java, Indonesia \\ Correspondence: Ayu Kusumastuti, Department of Sociology, Brawijaya University, Malang, East Java, Indonesia.
}

Received: November 30, 2017

Accepted: December 25, 2017

Available online: January 5, 2018

doi:10.11114/ijsss.v6i2.2825

URL: https://doi.org/10.11114/ijsss.v6i2.2825

\begin{abstract}
This article discuss at investigating the patterns, distribution, and stakeholders involved in the community empowerment program in Batu, East Java, Indonesia. By using the combination of Arc GIS (Geographic Information System) and Stakeholder Analysis, the community empowerment in Batu shows pragmatic and autocratic empowerment patterns. Besides, the community empowerment program in Batu is divided into 2 categories, namely exist/receive and does not exist/does not receive. The existing condition of empowerment program spreads unevenly. To deal with the issue, it is important to consider the Polycentric Development, which allows each region to have a Village Empowerment Center for equitable development. The city government has so far been the most dominant stakeholders in the empowerment program in Batu. Nevertheless, there are many other stakeholders starting to appear, such as private sectors and NGO, actors/individuals and media contributions, and universities. For recommendation, Government, private sectors, and non-governmental organizations can accommodate the principles of psychological empowerment, so that the empowerment is not only seen as a pragmatic-authoritarian impression. This principle is important because it can emotionally (intrapersonal) see someone's capacity to bring influence in making social changes and decisions. Communities as people who are exposed to empowerment programs need to actively increase participation. The next researcher can emphasize the stakeholder analysis on the collaboration and social networking patterns among them.
\end{abstract}

Keywords: empowerment, area distribution, area planning, and stakeholder analysis

\section{Introduction}

\subsection{Problem Area}

The history of development in Indonesia once placed a top down development model as an effective model for the community. However, along with the social and political development and dynamics, this development model is considered less relevant. Therefore, in the era after the new order, development has implemented bottom up development model. The development is more focused on community participation since then (Nikkhah, H. A., \& Redzuan, M, 2009).

One of the bottom up development entities is empowerment. Empowered communities are they who are able to identify the problems and have ways to solve the problems based on their potential. (Bhattacharyya, 2004). The examples of empowerment activities in Batu are a partnership among the dairy farmers with KUD Batu in improving the economy of the dairy farmers (Dewi, K. T., Hardjianto, I., \& Mindarti, L. I., 2011) and training and community programs to encourage tourism potentials (Muzha, V.K., 2013).

Stakeholders hold significant role in empowerment. The existence and involvement of intensive actors will bring a success for empowerment program (Achterkamp, M. C., \& Vos, J. F, 2008). Based on the above issue, the researchers propose the following research problems:

1. How is the pattern and distribution of community empowerment activities in Batu?

2. How do stakeholders involve and what is their interest in community empowerment activities in Batu?

\subsection{Empowerment: Definition and Principles}

Empowerment is the process of providing technical assistance, conducting evaluations, and improving local capacities 
(Fawcett et al., 1995). The efforts of community empowerment are actually inseparable from the psychological aspect (Christens, 2012). In the process as well, empowerment requires participation in its process (Perkins, 1995).

There are some activities performed in community empowerment, for example enhancing experience and competence, increasing group capacity, eliminating social and environmental constraints, increasing environmental supports and resources (Fawcett et al., 1995). According to McMillan, Florin, Stevenson, Kerman, \& Mitchell (1995), community coalition emphasizes the efforts to solve community problems by using community empowerment methods that promote individuals. Based on the context of Chinese society, the empowerment of elderly, families, children, adults, women, and marginalized groups (Yip, 2004) includes autocratic empowerment, pragmatic empowerment, indirect empowerment, lonely empowerment, and fashionable empowerment.

\subsection{Making Space: Spatial Planning and Development}

Spatial planning is defined as a change in the distribution/activities distribution to change land use and property (Nichersu \& Iacoboaea, 2011). The economic progress within the framework of spatial analysis can be seen from the rising trends of geographical (equity), demographic, infrastructure, industrial, agricultural and environmental development. However, asymmetric development cannot be established if the distribution of production and settlements is uneven (Imashev, 2014). Polycentric development is a development concept in which every locality/space/country must have specific goals to create development centers throughout the EU (Blăgeanu, 2014). In conceptualizing the space, there are at least two things to be taken into account. The first is the spatial problem that can be solved precisely and the second is addressing cognitive psychology or commonly called as a non-metric representation (Lynn, 2003).

\subsection{Stakeholder Theory}

Stakeholders are defined as individuals or group of individuals who can win or lose in a transaction (Doherty, 2009). Stakeholders are individuals or groups that have a stake in an organization (Kaler, 2002 dalam Fassin, 2009). Donaldson \& Preston (1995) defined stakeholders as persons or groups who have a legitimate interest in procedural or substantive aspects of working activities. Astakeholder theory refers to four social sciences: sociology, economics, politics and ethics (Wagner Mainardes, Alves, \& Raposo, 2012). Stakeholder theory explained the relationship between an organization/company and stakeholders is relational, not a transactional relationship (Myllykangas, Kujala, \& Lehtimäki, 2011).

This management approach takes place at three levels: identifying stakeholders, developing processes that recognize their own needs and interests, and building relationships among them based on the organizational goals (Wagner Mainardes et al., 2012). There are two most common categories of stakeholders, namely primary and secondary stakeholders. Primary stakeholders refer to the actors who directly gain benefit from an organization/program, while the secondary stakeholder is an actor outside the organization/program but they are affected by the program (Fassin, 2009). Secondary stakeholders refers to those who influence or are influenced by the organization, but they are not very influential in the organization/program (Clarkson, 1995). Besides, there are three main components of stakeholder analysis: Stakeholders Salience, Stakeholder Worldview, and Stakeholder Network (Kivits, 2011).

\section{Methodology}

\subsection{Arc GIS}

Geographic Information System (GIS) is a system of geographic management, analysis, and information. This geographic information is derived from a set of data that provides geographic structures or geo-references/locations in the real world (ESRI, 2004). GIS is also said to be a system decision supports that involves spatial integration and is widely used in urban planning (Manole, Petrisor, \& Tache, 2011). The traditional notion of GIS is a spatial data base, mapping tool, and spatial analysis tool (Sui \& Goodchild, 2003).

Geographic information data is an object and action in which geographic location becomes crucial information. Geographic information data comes from the data containing geographic location information displayed in multiple layers that can now be accessed via internet/Web GIS without having to buy GIS applications (Masron, Ismail, \& Marzuki, 2016). In this research, Arc GIS analysis is directed to Geodatabase and Geovizualization applications. Geodatabase uses the 2011 Village Potential data that was obtained through Ms Accsess in which the data is in the form of attribute data. The next data used is Rupa Bumi Indonesia (RBI) that is available in shapefile format. Then, the data is processed into a visualization that displays certain information (Geovizualization).

\subsection{Stakeholder Analysis}

This analysis takes a behavioral, interest, intercalation and interest approach of key actors/stakeholders to understand a system (Romanelli, Massone, \& Escalante, 2011). It is urgent to identify stakeholder governance in order to recognize the characteristics of individuals or groups that influence and are influenced by an organization/program (Wagner Mainardes 
et al., 2012). This analysis ensures that all interests in a particular area are considered in the planning process (Romanelli et al., 2011).

Researchers, in this study, categorize stakeholders into 2 parts, primary and secondary stakeholders. Researchers then identify the interest of the actors in a program to see if it is positive or negative to finally be able to notice the most important actors in the empowerment program.

\subsection{Methods Combination of Arc GIS and Stakeholder Analysis}

This research combines the methods of spatial and stakeholder analysis. The first method is to illustrate the thematic map about the spreading of community empowerment programs. Furthermore, the research also explores the social process in dispersal area by implementing stakeholder analysis, that is the identification of typology and stakeholder interests. Thus, comprehensive information on the distribution and program actors will be notified.

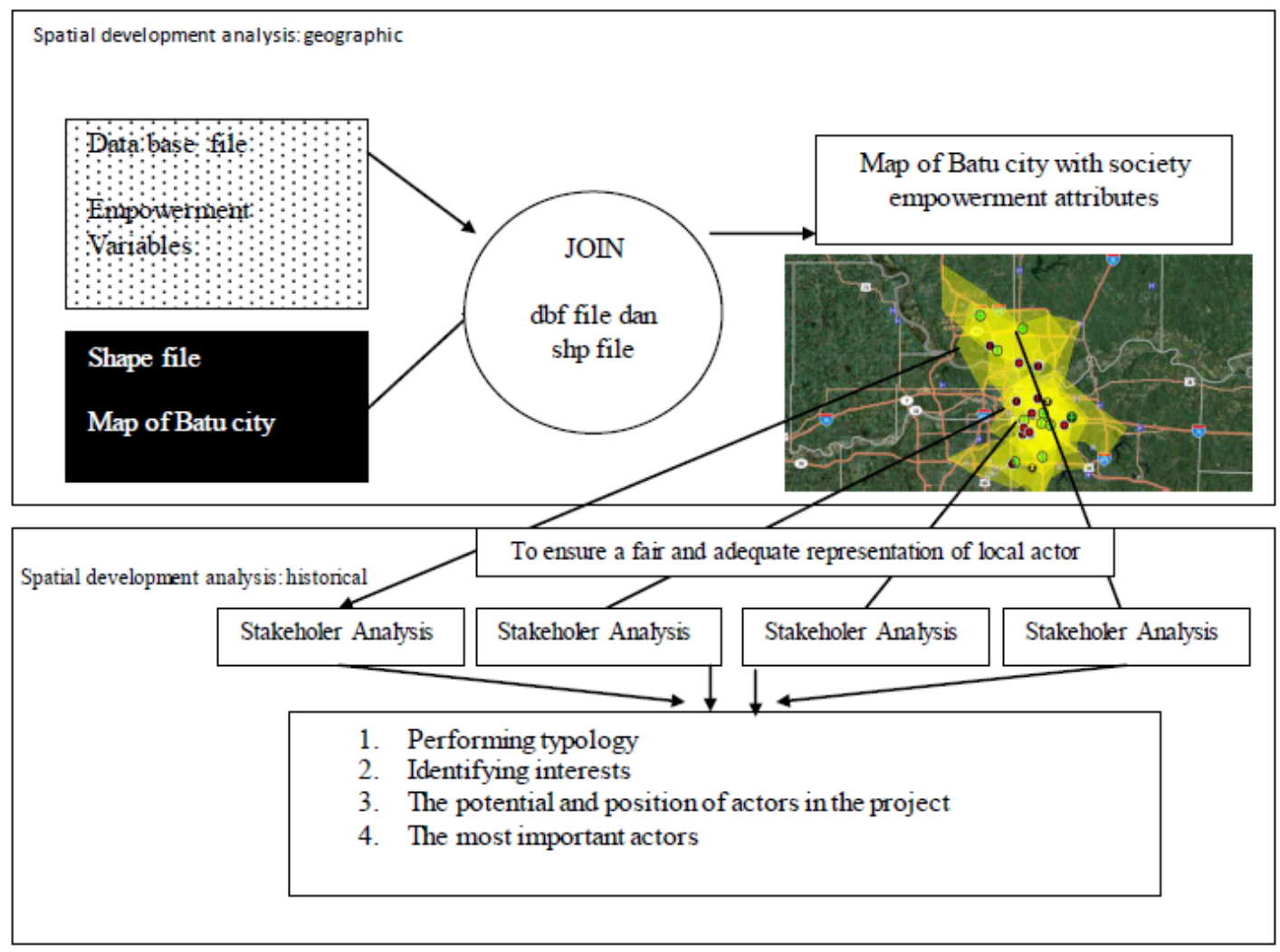

Picture 1. The Working Framework of Method Combination of Arc Gis and Stakeholder Analysis

\section{Result and Discussion}

\subsection{Study Area}

Based on the data of Village Potential of Malang from the Central Bureau of Statistics in 2014 by using spatial analysis method, there are four points that receive and do not receive the program of empowerment in economic and social sectors.

Table 2. The Locations of Empowerment Program Distribution

\begin{tabular}{lll}
\hline \multicolumn{1}{c}{ Empowerment Sector } & \multicolumn{1}{c}{ Status } & \multicolumn{1}{c}{ Research Location } \\
\hline $\begin{array}{l}\text { Economic Empowerment: revolving fund for agricultural business } \\
\text { capital, revolving fund for non-agricultural business capital, } \\
\text { revolving fund for productive business }\end{array}$ & Receive & Kelurahan Pesangrahan \\
$\begin{array}{l}\text { Social Empowerment: improvement of production skills, } \\
\text { improvement of production marketing skills, strengthening social } \\
\text { institution of society }\end{array}$ & Does Not Receive & Receive \\
\hline
\end{tabular}

Source: The 2014-BPS Analysis of Society Empowerment Variable 
Information:

1. Economic Empowerment: revolving fund for agricultural business capital, revolving fund for non-agricultural business capital (mining, industry, trade, tourism and services), and revolving fund for productive cultivation business (planned activities for the maintenance of biological resources such as: plant or farm), or non-cultivation (not related to biological resources, such as: making crafts, trade, transportation, workshop).

2. Social empowerment: improvement of production skill, improvement of production marketing skill, strengthening of social institution.

\subsection{The Patterns of Society Empowerment Program}

\subsubsection{Economy Empowerment: Kelurahan Pesanggrahan and Pandanrejo Village}

Pesanggrahan village has agricultural and livestock resources that are potential to be developed apart from its intensified physical development. There is one targeted smaller village (dusun) of empowerment. It is Dusun Toyomerto because its location is at the end of Pesanggrahan Village. It is often regarded as the most backward population. This condition becomes the concern for universities, agencies, NGOs to do empowerment for the people of Dusun Toyomerto. The most obvious empowerment received by the local residents in Toyomerto is the utilization of cattle waste into biogas.

In 2005 PT. Petrokimia Gresik provided empowerment and assistance of biogas installation equipment as a form of CSR from the company. The farmer group also presented the economic empowerment in the form of revolving fund or savings and loan to fulfill the operational needs of all farmers in Pesanggrahan Village. Re volving funds are usually obtained from the Department of Agriculture and Department of Cooperatives, Industry, and Trade to empower farmers. Associated with the type of empowerment undertaken by the Red and White NGOs in cooperation with PT Petrokimia Gresik, it includes a pragmatic empowerment in which the parties involved in it prioritize the utilization aspect.

In the ArcGis method that was derived from data of Village Potential in 2014, it was said that there was a village that did not receive economic empowerment, whih was Pandanrejo village. Contrary to the fact, this village even received many empowerment programs related to skill improvement, such as making strawberry juice. Strawberry juice is made by housewives who are members of KWT (Kelompok Wanita Tani- a group of female farmers). The process of making strawberry juice is performed in groups with the assistance from the Department of Agriculture and Department of Cooperatives, Industry, and Trade. In addition to agriculture, Pandanrejo village is also known as the only center of batik tulis in Batu. At first, the youth organization of Pandanrejo village, hand in hand with the Department of Cooperatives, Industry, and Trade, invited batik artists to provide training for the local residents. The performed empowerment is type of practical empowerment with active participation from both citizen and the department. It is defined as a pragmatic empowerment because the parties involved in the program prioritize benefits and results.

\subsubsection{Social Empowerment: Bulukerto Village and Mojorejo Village}

The Department of Agriculture provides funds for rural agribusiness development. The funds that have been given to the farmers group will be managed by the Joint Farmers' Group (GAPOKTAN) of Bulukerto village. In addition to the funds earned by GAPOKTAN, farmer groups also receive orange and apple seedlings.

Since the empowerment bases on autocratic ways or focuses on one person, it is defined as a top down empowerment. This makes GAPOKTAN face difficulties to innovate because the plants that will be planted by farmers have been mapped.

Mojorejo village also received empowerment in the economic aspect by receiving money for ten farmer groups. The funding to assist the population economy is directed to form cooperatives in each residents association, female union, farmer group union, and gapoktan union.

Universities also contribute in similar ways. They do direct assistance to residents of Mojorejo village in introducing machines that can help them in the aspect of agricultural production. The community empowerment conducted in Mojorejo village includes in the pragmatic type since it prioritizes practical aspects and direct benefits.

\subsection{From Asymmetric To Polycentric Development: Spatial Distribution of Community Empowerment Program}

By employing GIS Arc for processing the data of 2014's village potential, it is known that the distribution of this empowerment program is uneven. The following will explain the distribution map. 


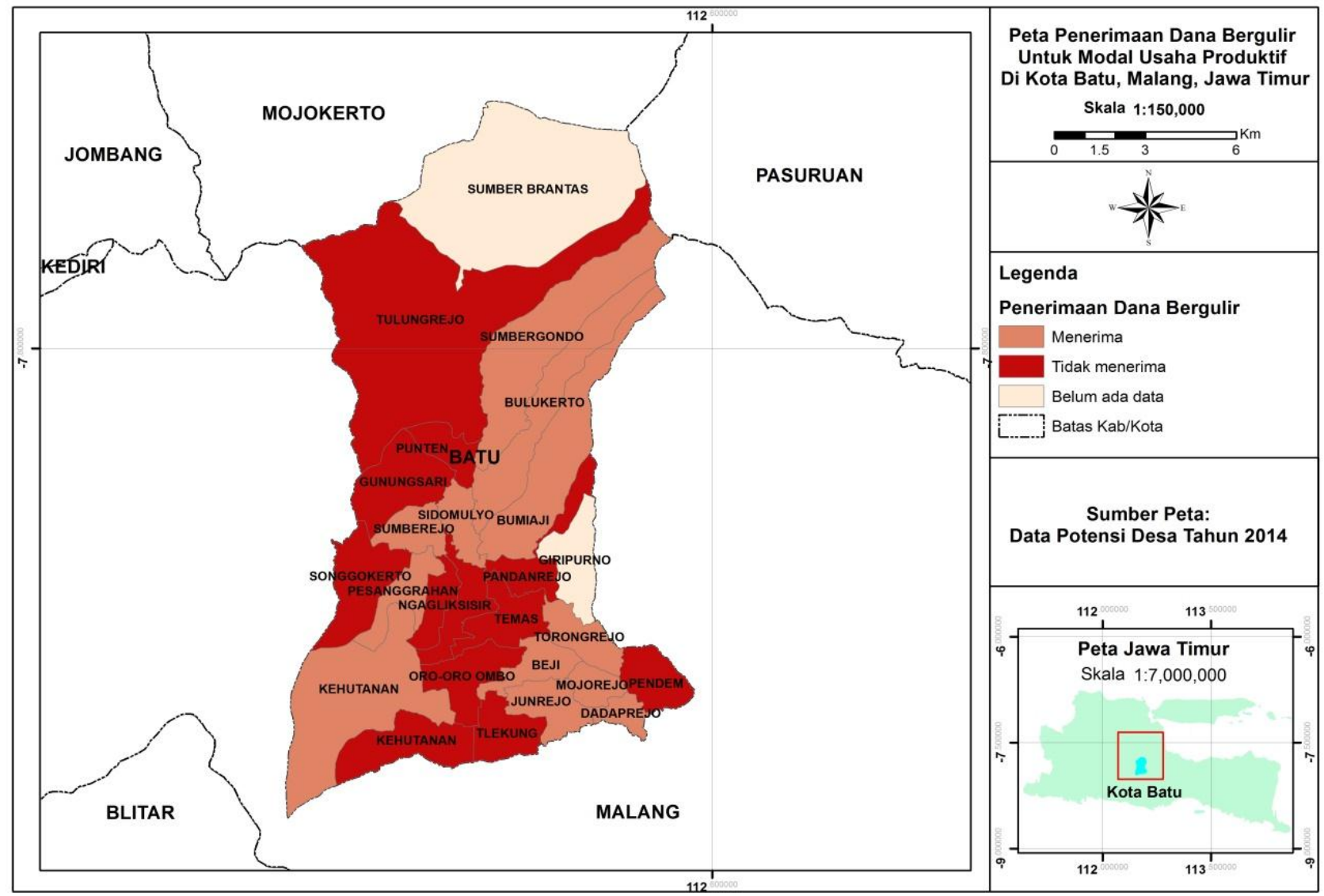

Picture 3. Rolling Reception for Productive Business Capital Cultivation in Batu, Malang, Jawa Timur

The above map illustrates the distribution of revolving revenues for productive business capital in Batu Cultivation. Productive business of this cultivation is a planned activity of biological resources maintenance such as: animal cultivation, on-farm cultivation, and non-cultivation that is not related to biological resources, such as: making handicrafts, trade, transportation, off farm. In Batu, there are 12 areas that received such empowerment models. Meanwhile, the other 11 villages do not receive productive venture capital. Based on that, it is clearly seen that the distribution of non productive empowerment program in Batu is uneven. It is actually a sign that the empowerment programs actually show asymmetric development. Asymmetric development refers to an une ven distribution of production, settlement, history, geography and economy (Imashev, 2014). 


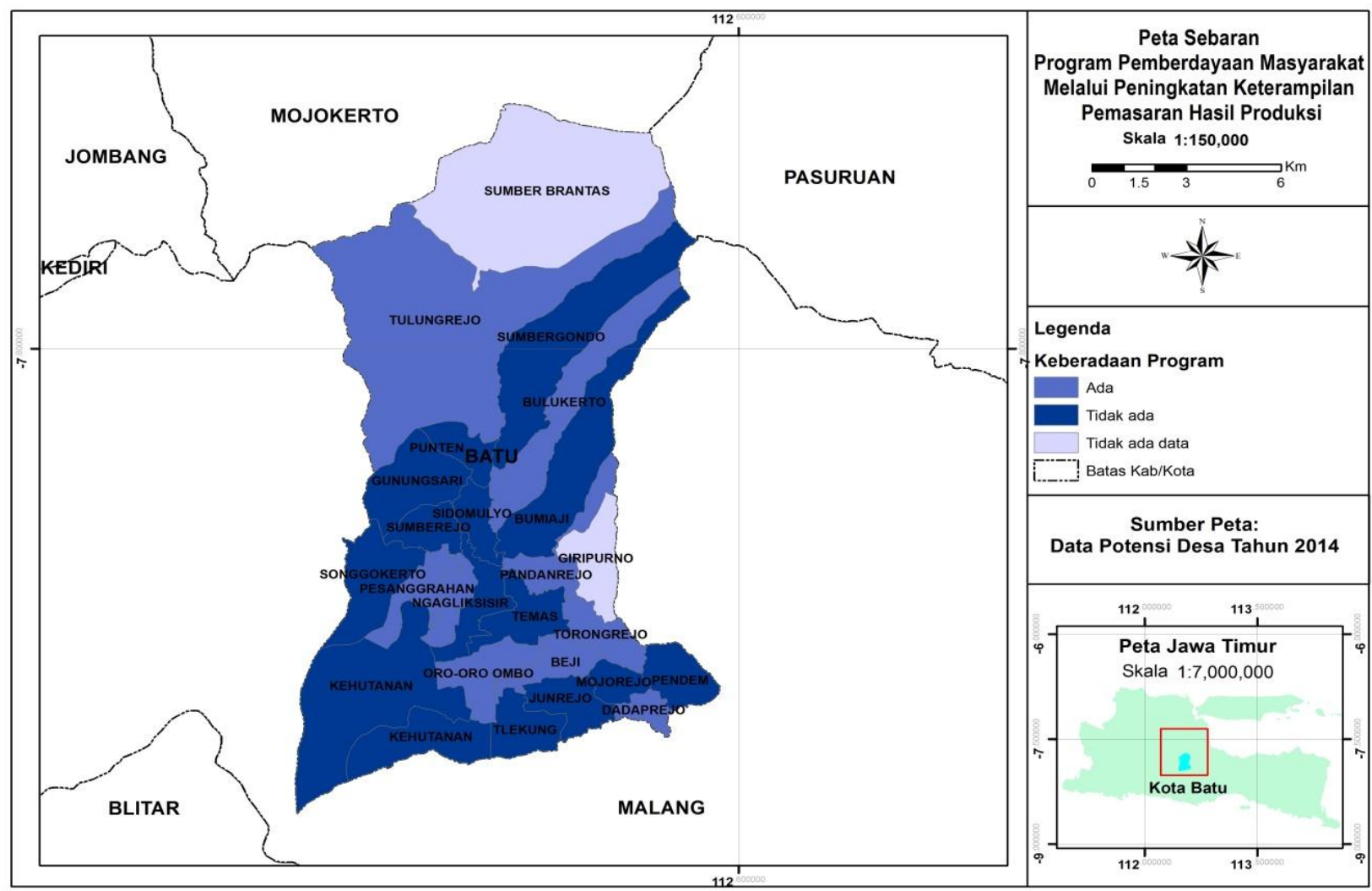

Picture 4. The Distribution of Community Empowerment Program by Improving Marketing Skills

The map above illustrates the distribution of community empowerment programs in the social sector by improving the production of marketing skills. The distribution encompasses 2 categories: there are programs in the region and there are no programs in the region. It indicates that there are 9 existing village areas of the program and 13 village areas that have not received such programs.

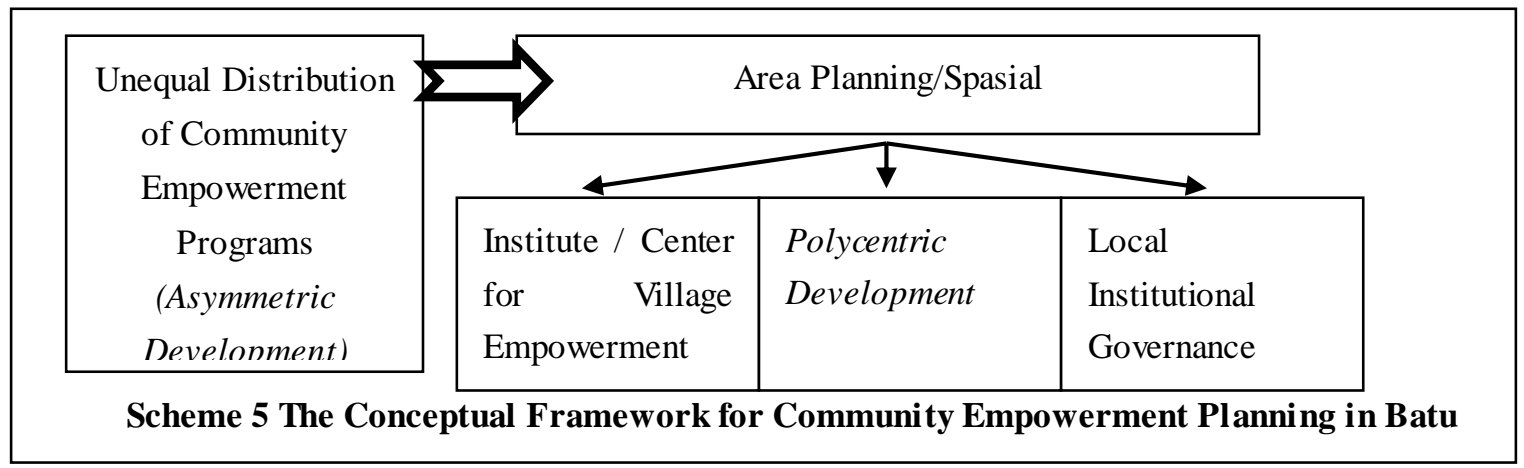

It is necessary to establish a Village Empowerment Center in each region as a forum for community gathering. This community center is an institution for learning, training, conveying ideas, meeting of power actors or agencies and discussions for citizens as an attempt to carry out community empowerment. This center is addressed by all communities without exception.

The establishment design of the Village Empowerment Center is located at the level of the smallest local government that is village. The purpose of this institution is that the community can identify the empowerment features that are appropriate to the local context and formulate local development goals. This kind of development adopts the principle of Polycentric development. Polycentric development is a development concept whereby every locality or space or country must have specific goals to create development centers (Blăgeanu, 2014).

The institute is of course equipped with established governance. Institutional governance is a set of rules, values and 
norms that were agreed by the society to achieve certain goals. This governance can be materialized by the board of the institution and also its organizational regulations. The right management system is a management that does not release the cultural and historical elements of the local community. This is in accordance with Lynn's (2006) statement that in conceptualizing space, there are at least 2 important things to consider. The first is about spatial problems and the second is cognitive psychology about history and culture aspects.

\subsection{The Stakeholder Analysis of Empowerment Program in Batu Community}

\subsubsection{Economic Sector Empowerment: Pesanggarahan Village and Pandanrejo Village}

There are at least 9 stakeholders who contribute to empowerment efforts in Pesanggarahan Village and the actors are from government, private and civil societies and uni versities. From the table it can be studied that there are 9 actors that can be divided into 2 categories, namely the primary and secondary actors. The primary category includes farmers and ranchers because they are the most profitable and direct link to a program. Municipal government agencies, NGOs, campuses as well as the private sectors become the secondary stakeholders because even though their presence affects and is influenced by empowerment programs, they are not in the program. Therefore, the empowerment activities are relatively viable.

Table 6. The Interests Stakeholder Community Empowerment Program

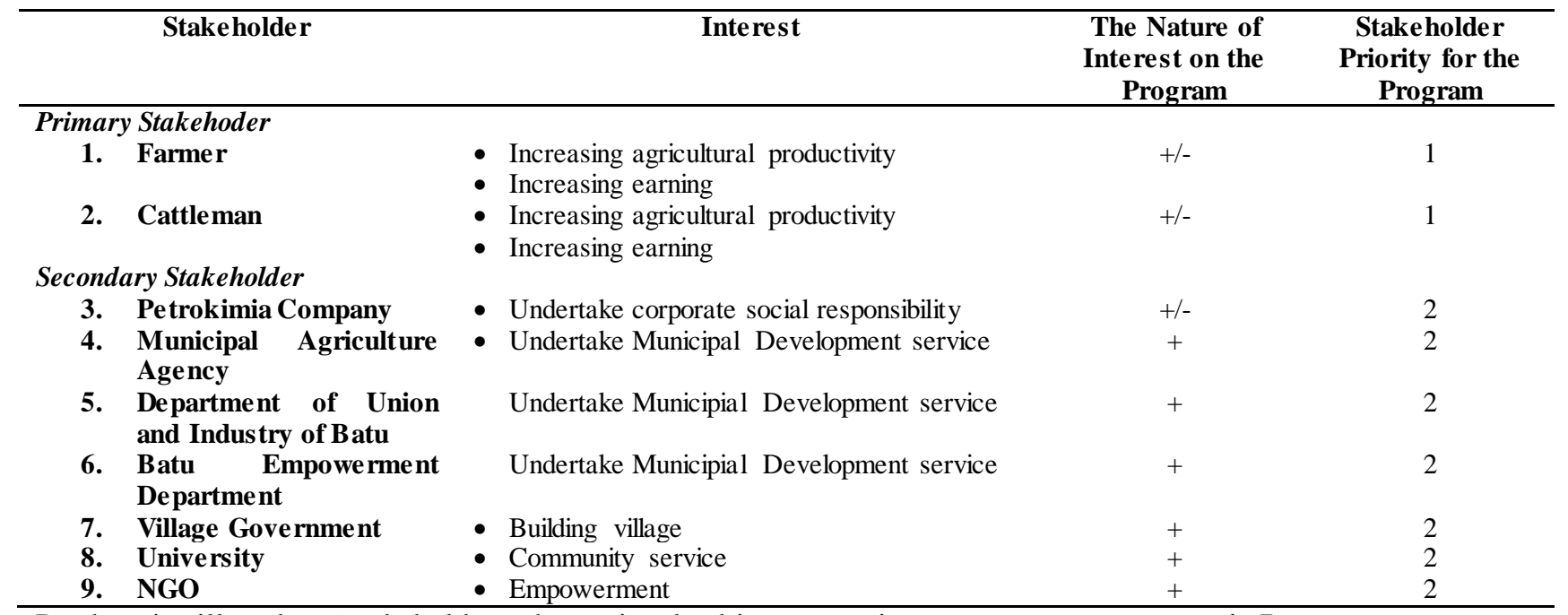

Pandanrejo village has 6 stakeholders who are involved in community empowerment programs in Batu.

Table 7. The Stakeholders of Social Economic Sector of Empowerment Program in Pandanrejo Village

\begin{tabular}{|c|c|c|c|}
\hline Stakeholder & Interest & $\begin{array}{l}\text { The Nature of } \\
\text { Interest on the } \\
\text { Program }\end{array}$ & $\begin{array}{c}\text { Stakeholder } \\
\text { Priority for the } \\
\text { Program }\end{array}$ \\
\hline \multicolumn{4}{|l|}{ Primary Stakehoder } \\
\hline 1. Farmer & $\begin{array}{l}\text { - Increasing Earning } \\
\text { - Increasing agriculture productivity }\end{array}$ & $+/-$ & 1 \\
\hline 2. House wives & - Additional income & + & 1 \\
\hline $\begin{array}{l}\text { Secondary Stakeholder } \\
\text { 3. Agriculture Service }\end{array}$ & - Undertake an official program & + & 2 \\
\hline $\begin{array}{l}\text { 4. Union Service, Industry } \\
\text { and Commerce }\end{array}$ & $\begin{array}{l}\text { - Undertake an official program } \\
\text { - Municipial Development }\end{array}$ & + & 2 \\
\hline \multicolumn{4}{|l|}{ External Stakeholder } \\
\hline 5. Mass media & - Promoting the batik motive of Batu & + & 2 \\
\hline 6. Individual (Ms Lina) & - Transfer knowledge & + & 2 \\
\hline
\end{tabular}

\subsubsection{Social Sector Empowerment: Bulukerto village and Mojorejo village}

There are 7 actors who are involved in empowerment program in Bulukerto village. 
Table 8. The Stakeholders of Social Economic Sector of Empowerment Program of Bulukerto Village

\begin{tabular}{|c|c|c|c|}
\hline Stakeholder & Interest & $\begin{array}{c}\text { The Nature of } \\
\text { Interest on the } \\
\text { Program } \\
\end{array}$ & $\begin{array}{c}\text { Stakeholder } \\
\text { Priority for the } \\
\text { Program } \\
\end{array}$ \\
\hline $\begin{array}{c}\text { Primary Stakehoder } \\
\text { 1. Farmer }\end{array}$ & - Increasing Earning & $+/-$ & 1 \\
\hline 2. PKK & $\begin{array}{l}\text { - Increasing agriculture productivity } \\
\text { - Additional income }\end{array}$ & $+/-$ & 1 \\
\hline $\begin{array}{l}\text { Secondary Stakeholder } \\
\text { 3. Agriculture Service }\end{array}$ & $\begin{array}{l}\text { - Undertake an official program } \\
\text { - Municipal Development }\end{array}$ & + & 2 \\
\hline 4. Village Government & $\begin{array}{l}\text { - Village development through the } \\
\text { construction of a fertilizer barn }\end{array}$ & + & 2 \\
\hline $\begin{array}{l}\text { 5. Combined Farmer } \\
\text { Group }\end{array}$ & $\begin{array}{l}\text { - Advocacy on government, to provide } \\
\text { assistance as needed }\end{array}$ & $+/-$ & 2 \\
\hline $\begin{array}{l}\text { 6. The Society of } \\
\text { Bulukerto Village }\end{array}$ & $\begin{array}{l}\text { - Demo at Gemulo water source } \\
\text { - The initiator of folk festivals, the water } \\
\text { festival }\end{array}$ & $+/-$ & 2 \\
\hline 7. Mass Media & - Building public opinion & - & 3 \\
\hline
\end{tabular}

The next village is Mojorejo village. There are 7 actors who are involved in community empowerment in Mojorejo village.

Table 9. Stakeholders' Interest of Social Economy Sector of Empowerment Program in Mojorejo Village

\begin{tabular}{|c|c|c|c|}
\hline Stakeholder & Interest & $\begin{array}{c}\text { The Nature of } \\
\text { Interest on the } \\
\text { Program }\end{array}$ & $\begin{array}{c}\text { Stakeholder } \\
\text { Priority for the } \\
\text { Program }\end{array}$ \\
\hline \multicolumn{4}{|l|}{ Primary Stakehoder } \\
\hline 1. Farmer & - Increasing earning & $+/-$ & 1 \\
\hline 2. PKK & - Additional Income & $+/-$ & 1 \\
\hline Seconday Stakeholder & - Undertake an official program & + & 2 \\
\hline $\begin{array}{l}\text { 3. Union Service, Industry } \\
\text { and Commerce }\end{array}$ & - Municipial Development & & \\
\hline 4. Agriculture Service & $\begin{array}{l}\text { - Undertake an official program } \\
\text { - Municipial Development }\end{array}$ & + & 2 \\
\hline $\begin{array}{l}\text { 5. 5. De partment of } \\
\text { Empowerment }\end{array}$ & $\begin{array}{l}\text { - Undertake an official program } \\
\text { - Municipial Development }\end{array}$ & + & 2 \\
\hline 6. Village Government & - The interests of village development & + & 2 \\
\hline 7. Universities & - Community service of the university & + & 3 \\
\hline
\end{tabular}

Of the 4 villages that have been analyzed, it is known that the key players in urban community empowerment are still from the city service although there are many other different actors. In Pesanggrahan village there are other actors from private sectors and NGOs. In Pandanrejo village there are individual actors who give a lot of contribution in empowerment. Meanwhile, in Bulukerto village there is contribution of mass media and in Mojorejo village there is a university supporting the village's development. Different styles of empowering actors in each village make the pattern of empowerment also different.

\subsubsection{Stakeholder Recapitulation}

This stakeholder recapitulation attempts to compare the four villages that appear as an analytical unit to identify the emerging interests. Therefore, it can be seen here that the stakeholders hold their crucial role in undertaking the organization because its existence can influence and be influenced by the organization or program.

Table 10. Stakeholder Recapitulation

\begin{tabular}{|c|c|c|c|c|}
\hline Stakeholder & Pesanggrahan & Pandanrejo & Bulukerto & Mojorejo \\
\hline $\begin{array}{ll}\text { Number } & \text { of } \\
\text { stakeholder }\end{array}$ & 9 & 6 & 7 & 7 \\
\hline Positive (+) & 6 & 5 & 2 & 5 \\
\hline Negative (-) & 0 & 0 & 1 & 0 \\
\hline Positive and negative & 3 & 1 & 4 & 2 \\
\hline
\end{tabular}

It is known from the table above that in the Pesanggrahan village there are 9 stakeholders, 6 stakeholders in Pandanrejo Village, 7 in Mojorejo village. In Pesanggrahan village there are 6 positive stakeholders, 3 positive or negative 
stakeholders and no negative stakeholders. This means that many positive stakeholders contribute to the success of the empowerment program. The more number of stakeholders in the positive category means that the management of the program runs more effective because there are many parties contributing to the effectiveness of the program.

The more number of stakeholders in the positive or negative category is assumed that the management of the program can be effective or ineffective because many of the contributing parties hinder the program.

In Mojorejo village there are 5 positive stakeholders, 2 positive or negative stakeholders, and no negative stakeholders. This means that many positive stakeholders indicate that many actors contributed to the success of the empowerment program.

Table 11. The Last Mapping of Distribution and Stakeholder Analysis

\begin{tabular}{|c|c|c|c|c|c|}
\hline No. & Village Names & $\begin{array}{l}\text { Characteristics } \\
\text { Empowerment Variables } \\
\text { (Potential Village Data, BPS } \\
\text { 2014) } \\
\text { Distribution Analysis }\end{array}$ & $\begin{array}{l}\text { Number of } \\
\text { Stakeholder }\end{array}$ & & $\begin{array}{l}\text { Kind of Empowerment } \\
\text { Exists in the field }\end{array}$ \\
\hline & $\begin{array}{l}\text { Pesanggrahan Village } \\
\text { (Pragmatic } \\
\text { Empowerment) }\end{array}$ & $\begin{array}{l}\text { Receiving } \\
\text { empowerment } \\
\text { (revolving fund) }\end{array}$ & $\begin{array}{l}9 \\
\text { stakeholder }\end{array}$ & $\begin{array}{l}\text { Many } \\
\text { contribute to actors } \\
\text { success of the } \\
\text { program }\end{array}$ & $\begin{array}{l}\text { Give more trainings and } \\
\text { providing } \\
\text { knowledge/skills }\end{array}$ \\
\hline & $\begin{array}{l}\text { Pandanrejo Village } \\
\text { (Pragmatic } \\
\text { Empowerment) }\end{array}$ & $\begin{array}{l}\text { Does not receive economy } \\
\text { empowerment } \\
\text { (revolving fund) }\end{array}$ & $\begin{array}{l}6 \\
\text { stakeholder }\end{array}$ & $\begin{array}{l}\text { Many actors } \\
\text { contribute to the } \\
\text { success of the } \\
\text { program }\end{array}$ & $\begin{array}{l}\text { Save-loan in village leve } 1 / \\
\text { residents association and } \\
\text { farmer groups }\end{array}$ \\
\hline & $\begin{array}{l}\text { Bulukerto Village } \\
\text { (Autocratic } \\
\text { Empowerment) }\end{array}$ & $\begin{array}{l}\text { Receiving } \\
\text { empowerment (production } \\
\text { skills, marketing and } \\
\text { institutional) }\end{array}$ & $\begin{array}{l}7 \\
\text { stakeholder }\end{array}$ & $\begin{array}{l}\text { Many parties' } \\
\text { contributions and } \\
\text { obstacles for the } \\
\text { program. }\end{array}$ & $\begin{array}{l}\text { Training of fertilizer } \\
\text { processing, } \\
\text { Flower } \\
\text { training }\end{array}$ \\
\hline & $\begin{array}{l}\text { Mojorejo Village } \\
\text { (Pragmatic } \\
\text { Empowerment) }\end{array}$ & $\begin{array}{l}\text { Does not receive social } \\
\text { empowerment } \\
\text { (production skill, marketing } \\
\text { and instituonal) }\end{array}$ & $\begin{array}{l}7 \\
\text { stakeholder }\end{array}$ & $\begin{array}{l}\text { Many actors } \\
\text { contribute to the } \\
\text { success of the } \\
\text { program }\end{array}$ & $\begin{array}{l}\text { Training of producing } \\
\text { chips and crackers } \\
\text { production, } \\
\text { abon (catfish and tuna) }\end{array}$ \\
\hline
\end{tabular}

\section{Conclusion}

The pattern of community empowerment in Batu shows a pattern of pragmatic and autocratic empowerment. Pragmatic empowerment is a process of empowerment in which the parties who are involved in it prioritize the aspects of practicality, usefulness and results (Yip, 2004). This is supported by the form of empowerment program available in 3 villages that have the characteristics of providing material assistance and some strengthening capacity and skills. Such forms of empowerment activity show that there are clear and direct results that can be enjoyed by the community, even though the independence of the community in such a pattern of empowerment tends to be somewhat low.

The pattern of autocratic empowerment can be seen in Bulukerto village. This empowerment uses autocratic work or centralized decisions on one person and is usually done by bureaucratic workers (Yip, 2004). It can be seen that the existing empowerment activities are the provision of fertilizer, apple seedlings and citrus seedlings and savings and loans for farmers' productivity. The key player in this empowerment program is the Department of Agriculture.

The present patterns of empowerment are spread unevenly in Batu. Based on the results of GIS Arc analysis, it is known that community empowerment program in Batu is divided into 2 categories, namely exist or receive and does not exist or does not receive. The researcher does the tracking in the field to see if the categorized area does not receive the program. Actually they received another empowerment activity such as direct aid funds. The program distribution in a certain area can actually be anticipated by applying Polycentric Development. In each region it is necessary to establish a Village Empowerment Center as a forum for community gathering. This community center is an institution for learning, training, conveying ideas, meeting of power actors or agencies and discussions for citizens in community empowerment efforts.

\section{Recommendation}

\subsection{For Social Worker Who will Perform the Empowerment}

The government, private sectors, and non-governmental organizations can accommodate the principles of psychological empowerment to avoid an impression of merely pragmatic-authoritarian. The psychological empowerment becomes important because it can view the capacity of someone that can emotionally (intrapersonal) be influential in making social changes and decisions (Christens, 2012). Some activities that can be performed in community empowerment are enhancing experience and competence, increasing group capacity, and increasing environmental and resource support 
(Fawcett et al., 1995). All process is performed by doing collaboration process of all parties related to empowerment. Furthermore this process is called a community coalition (collective process) (McMillan, Florin, Stevenson, Kerman, \& Mitchell (1995).

\subsection{For Villagers}

Communities as people who are exposed to empowerment programs need to actively increase participation. Participation can affect or be influenced by empowerment efforts. Participation allows the community to have an ownership of empowerment activities. Each region also needs to establish Village Empowerment Center as a forum for community gathering.

\subsection{For the Next Researchers}

The next researcher can emphasize the stakeholder analysis on the collaboration and social networking patterns among them. Seeing collaboration among stakeholders in community empowerment is important to know how good governance capacity is at the local or regional level.

\section{Funding}

This research was funded by Institute of Research and Community Services Universitas Brawijaya (LPPM), Indonesia DIPA 042.01.2.400919/2017.

\section{References}

Achterkamp, M. C., \& Vos, J. F. (2008). Investigating the use of the stakeholder notion in project management literature, a meta-analysis. International Journal of Project Management, 26(7), 749-757. https://doi.org/10.1016/j.ijproman.2007.10.001

Bhattacharyya, J. (2004). Theorizing community development. Community Development, 34(2), 5-34. https://doi.org/10.1080/15575330409490110

Blăgeanu, A. (2014). POLYCENTRISM, STRATEGIC SPATIAL PLANNING AND ITS IMPLICATIONS Alexandra BLĂGEANU. Scientific Annals Of "AI.I.CIZA" University of IASI Geography Series, LX(2). https://doi.org/http://dx.doi.org/10.15551/scigeo.v60i2.336

Christens, B. D. (2012). Toward Relational Empowerment. American Journal of Community Psychology, 50(1-2), 114-128. https://doi.org/10.1007/s 10464-011-9483-5

Clarkson, M. B. . (1995). A Stakeholder Framework for Analyzing and Evaluating Corporate Social Performance. The Academy of Management Review, 20(1), 92-117. Retrieved from http://www.jstor.org/stable/258888

Dewi, K. T., Hardjianto, I., \& Mindarti, L. I. (2011). Kemitraan peternak sapi perah dengan KUD "Batu" dalam meningkatkan ekonomi masyarakat peternak sapi perah. Jurnal Administrasi Publik(JAP), 1(4), 73-82.

Doherty, Mi. (2009). â€ $€^{\mathrm{TM}}$ REALIST â $€^{\mathrm{TM}}$ STAKEHOLDER ANALYSIS IN DESIGN.

Donaldson, T., \& Preston, L. E. E. E. (1995). The Stakeholder Theory of the Corporation: Concepts , Evidence , and Implications. The Academy of Management Review, 20(1), 65-91. Retrieved from http://www.jstor.org/stable/258887

ESRI. (2004). What is ArcGIS? Redland, CA, USA: ESRI.

Fassin, Y. (2009). The stakeholder model refined. Journal of Business Ethics, 84(1), 113-135. https://doi.org/10.1007/s 10551-008-9677-4

Fawcett, S. B., Paine-Andrews, A., Francisco, V. T., Schultz, J. a., Richter, K. P., Lewis, R. K., ... Lopez, Christine, M. (1995). Using Empowerment Theory in Collaborative Partnership for Community Health and Development. American Journal of Community Psychology, 23(5), 677-697. https://doi.org/10.1007/BF02506987

Imashev, E. (2014). REGULATION OF THE ASYMMETRY IN SPATIAL SOCIAL AND ECONOMIC DEVELOPMENT OF THE WEST KAZAKHSTAN REGION. In CBU International Conference of Innovation, Technology Transfer and Education (pp. 256-266). Prague,: WWW.CBUNI.CZ, OJS.JOURNALS.CZ. https://doi.org/10.12955/cbup.v2.479

Kivits, R. A. (2011). Three component stakeholder analysis. International Journal of Multiple Research Approaches, 5(3), 318-333. https://doi.org/10.5172/mra.2011.5.3.318

Lynn, S. (2003). Extending Space: Exploring the Territory of Spatial Development. Human Development, Jan/Feb 20(46), 6 ' . https://doi.org/10.1159/000067777

Manole, S. D., Petrisor, A. I., \& Tache, A. (2011). GIS Assessment of Development Gaps Among Romanian 
Administrative Units. Theoretical and Empirical Researches in Urban Management, 6(2011), 5-19.

Masron, T., Ismail, N., \& Marzuki, A. (2016). The Conceptual Design and Application of Web-Based Tourism Decision Support System. Theoretical and Empirical Researches in Urban Management,11(2), 64-75.

McMillan, B., Florin, Pa., Stevenson, J., Kerman, B., \& Mitchell, E. (1995). Empowerment Praxis in Community Coalitions. American Journal of Community Psycology, 23(5), 699. https://doi.org/10.1007/BF02506988

Muzha, V. K. (2013). Pengembangan agrowisata dengan pendekatan Community Based Tourism (Studi pada Dinas Pariwisata Kota Batu dan Kusuma Agrowisata Batu). Jurnal Administrasi Publik, 1(3), 135-141

Myllykangas, P., Kujala, J., \& Lehtimäki, H. (2011). Analyzing the Essence of Stakeholder Relationships: What do we Need in Addition to Power, Legitimacy, and Urgency? Journal of Business Ethics, (2010), 1-8. https://doi.org/10.1007/s10551-011-0945-3

Nichersu, I., \& Iacoboaea, C. (2011). Systematic Spatial Planning. Theoretical and Empirical Researches in Urban Management, 6(May 2011),67-77.

Nikkhah, H. A., \& Redzuan, M. (2009). Participation as a medium of empowerment in community development. European Journal of Social Sciences, 11(1), 170-117

Perkins, D. D. (1995). Speaking truth to power: Empowerment ideology as social intervention and policy. American Journal of Community Psychology, 23(5), 765-794. https://doi.org/10.1007/BF02506991

Romanelli, A., Massone, H. E., \& Escalante, A. H. (2011). Stakeholder analysis and social-biophysical interdependencies for common pool resource management: La Brava Wetland (Argentina) as a case study. Environmental Management, 48(3), 462-474. https://doi.org/10.1007/s00267-011-9698-0

Sui, D. Z., \& Goodchild, M. F. (2003). A tetradic analysis of GIS and society using McLuhan's law of the media. Canadian Geographer, 47(1), 5-17. https://doi.org/10.1111/1541-0064.02e08

Wagner Mainardes, E., Alves, H., \& Raposo, M. (2012). A model for stakeholder classification and stakeholder relationships. Management Decision, 50(10), 1861-1879. https://doi.org/10.1108/00251741211279648

Yip, K. (2004). The Empowerment Model : A Critical Reflection in Chinese Culture. Social Work, 49(3), 479-487. https://doi.org/10.1093/sw/49.3.479

\section{Copyrights}

Copyright for this article is retained by the author(s), with first publication rights granted to the journal.

This is an open-access article distributed under the terms and conditions of the Creative Commons Attribution license which permits unrestricted use, distribution, and reproduction in any medium, provided the original work is properly cited. 